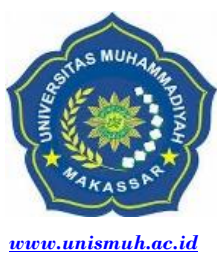

\title{
Eksistensi Majelis Ta’lim Asyifah di Kecamatan Pattallassang Kabupaten Takalar
}

\author{
Hidayah Quraisy ${ }^{1)}$ \& Jamaluddin Arifin ${ }^{2)}$ \\ Pendidikan Sosiologi FKIP Universitas Muhammadiyah Makassar \\ hidayahquraisy@unismuh.ac.id ${ }^{1)}$ \& jamaluddinarifin@unismuh.ac.id ${ }^{2)}$
}

\begin{abstract}
Majelis Ta'lim is a non-formal Islamic educational institution that can give a considerable contribution in the formation of morals and personal Muslims in accordance with the guidance of Rasulullah SAW. This study aims to determine the factors causing no successor Assembly Ta'lim Asyifah In Pattalassang District Takalar regency, to know the process of the successor of Majelis Ta'lim Asyifah In Pattallassang District Takalar District. The type of research used is descriptive qualitative research method by way of determining the sample through Purposive Sampling technique by selecting some informants who have criteria that have been determined by the researcher who knows about the Assembly Ta'lim Assyifah. This research is supported by data collection is done by observation, interview, documentation of the photo. The results showed that in general the factors causing the absence of the successor of Majelis Ta'lim Asyifah were the lack of socialization about the activities of Majelis Ta'lim, the absence of other people's interest in joining Majelis Ta'lim Asyifah, the absence of spare time to follow the activities of Majelis Ta'lim Asyiah. The process of the creation of the successor of Majelis Ta'lim Asyifah is to increase the socialization of the existence of Majelis Ta'lim's activities.
\end{abstract}

Keywords: Majelis Ta'lim, Socialization, Society

\begin{abstract}
Abstrak. Majelis Ta’lim merupakan lembaga pendidikan islam non formal yang dapat memberikan konstribusi cukup besar dalam pembentukan akhlak dan pribadi muslim sesuai dengan tuntunan Rasulullah SAW. Penelitian ini bertujuan untuk mengetahui faktor-faktor penyebab tidak adanya penerus Majelis Ta`lim Asyifah Di Kecamatan Pattalassang Kabupaten Takalar, untuk mengetahui proses terciptanya penerus Majelis Ta`lim Asyifah Di Kecamatan Pattallassang Kabupaten Takalar. Jenis penelitian yang digunakan adalah metode penelitian deskriptif kualitatif dengan cara penentuan sampel melalui teknik Purposive Sampling dengan memilih beberapa informan yang memiliki kriteria yang telah ditentukan oleh peneliti yakni yang mengetahui tentang Majelis Ta`lim Asyifah. Penelitian ini ditunjang dengan pengumpulan data dilakukan dengan cara observasi, wawancara, dokumentasi dari foto. Hasil penelitian menujukkan bahwa secara umum faktor penyebab tidak adanya penerus Majelis Ta`lim Asyifah adalah kurangnya sosialisasi tentang kegiatan Majelis Ta 'lim, tidak adanya minat masyarakat lain bergabung dengan Majelis Ta’lim Asyifah, tidak adanya waktu luang untuk mengikuti kegiatan Majelis Ta`lim Asyiah. Adapun proses terciptanya penerus Majelis Ta`lim Asyifah yaitu memperbanyak sosialisasi tentang adanya kegiatan Majelis Ta`lim.
\end{abstract}

Kata Kunci: Majelis Ta`lim, Sosialisasi, Masyarakat 


\section{PENDAHULUAN}

Allah menciptakan bumi berbeda dengan bulan dan bintang-bintang. Bumi dihiasi dengan kehidupan, udara bersih, iklim yang bersih, iklim yang sehat dan tumbuh-tumbuhan yang beraneka ragam. Kemudian Allah menciptakan makhluk yang paling sempurna yaitu manusia. Manusia dilengkapi akal dan kekuatan yang dapat membuka pintu ilmu. Manusia diberi kesadaran dan kebebasan untuk memilih jalan hidup. Semua itu dimaksudkan agar manusia dapat menjalankan fungsinya sebagai kholifah di muka bumi.

Pada hakikatnya manusia mempunyai kecenderungan untuk bertuhan. Manusia dalam hidupnya mempunyai tiga fungsi yang harus diemban, yaitu sebagai makhluk religius, sebagai makhluk sosial, dan sebagai makhluk individu. Sebagai makhluk religius. Manusia dilahirkan telah memiliki atau membawa bakat untuk percaya kepada Allah. Sebagai makhluk sosial, manusia akan selalu berhubungan atau membutuhkan orang lain dalam hidupnya. Begitu juga sebagai makhluk individu, manusia mempuyai kemandirian akan tetapi bersifat mandirinya itu tidak akan bertahan lama dan berjalan baik dengan karena dibalik itu terdapat sifat kebersamaan. Manusia tidak bisa hidup seorang diri tanpa bantuan orang lain baik dalam masyarakat, keluarga dan tempat lain. Beban manusia akan lebih gampang bila ada bantuan dari orang lain.

Kerusakan masyarakat disekitar kita dirasakan bertambah hari ke hari. Tindak kejahatan begitu menjamur sehingga media massa tidak pernah kehabisan berita kriminal setiap harinya. Korupsi, kolusi, suap sudah menjadi perkara biasa disemua lapisan masyarakat, bahkan menjadi kejadian langka apabila tidak terjadi korupsi, kolusi dan suap. Perzinaan, pornografi dan pornoaksi begitu marak, demikian juga angka pengidap HIV/AIDS. Begitu banyak bukti untuk mengatakan masyarakat kita sedang sakit parah, sehingga harus ada upaya yang ditempuh untuk memperbaiki kondisi masyarakat saat ini. Sebagai muslim, tentunya kita menginginkan perubaham masyarakat yang rusak saat ini menjadi masyarakat islam. Kaum muslimin harus diselamatkan dari kehinaan yang mereka alami dengan cara megajak mereka untuk berjuang menegakkan syariat islam dibawah nauangan Allah yang dapat menjadi kesejahteraan hidup di dunia dan tentu saja kebahagiaan hidup di akhirat.

Perkembangan zaman dan teknologi yang begitu pesat membuat semua orang terlena, bahkan lalai dan lengan terutama generasi muda dan masyarakat yang tidak dilandasi oleh keimanan dan ketakwaan, serta pendidikan agama yang tidak memadai membuat mereka semakin terperosok ke dalam lumpur yang penuh dengan dosa dan nista. Sehingga kata "DOSA" bukan lagi sebuah hal yang menakutkan bagi sebagian orang, tapi malah membuatnya merasa bangga dengan apa yang telah dilakukan, padahal itu perbuatan "DOSA". Sementara pendidikan formal yang mereka miliki tidak cukup untuk membentuk akhlak dan pribadi yang dapat mencegah mereka dari "Nahi dan Mungkar"

Melihat kondisi masyarakat saat ini, sebagai muslim, tentunya kaum muslimin harus diselamatkan dari kehinaan yang dialami dengan cara mengajak untuk berjuang menegakkan syariat islam dibawah naungan Al Quran dan Hadist yang menjamin kesejahteraan hidup di dunia dan tentu saja kebahagiaan hidup di akhirat.

Peran agama islam dalam pembinaan umat manusia menjadikan manusia sebagai makhluk yang sempurna. Umat islam adalah masyarakat yang berpondasikan persaudaraan, cinta kasih, saling menolong, dan menasehati. Tidak ada perbedaan kulit putih dan kulit hitam, besar dan kecil, kaya dan miskin. Melalui islam, manusia mengetahui sejarah, yakni sejarah yang dimulai sejak Allah menciptakan makhluk hingga sekarang ini. Dengan islam, manusia menyadari masa depannya dan tempat kembalinya. Tuhan menentukan tujuan hidup dan memerintahkannya agar manusia meniti jembatan ke sana kelak. Manusia akan memperoleh kebahagiaan sesuai dengan usaha dan amalnya.

Islam sebagai agama yang menjadi pedoman hidup bagi manusia mencakup seluruh kehidupan manusia. Disamping sebagai pedoman hidup, islam menurut para pemeluknya juga sebagai ajaran yang 
harus dida'wahkan dan memberikan pemahaman terhadap ajaran yang terkandung didalamnya. Sarana yang dapat dilakukan dalam mentransformasikan nilai-nilai agama tersebut antara lain melalui Majelis Ta'lim yang berfungsi memberikan pemahaman tentang nilai-nilai ajaran tersebut.

Majelis Ta`lim merupakan salah satu lembaga non formal yang dapat memberikan konstribusi cukup besar dalam pembentukan akhlak dan pribadi muslim sesuai dengan tuntunan Rasulullah. Terlepas dari itu semua, Majelis Ta'lim merupakan kombinasi yang sangat penting dalam sendi-sendi kehidupan masyarakat muslim pada khususnya, selain dalam rangka pengahayatan, pengalaman dan pelaksanaan ajaran agama juga sebagai peneguhan syair-syair dalam islam. Oleh karena itu menjadi sebuah tugas bersama yang harus diperhatikan dan didukung oleh semua pihak, sehingga rencana yang mulia ini dapat terlaksana secara maksimal dan semakin menambah semangat dalam memperjuangkan nilai-nilai agama islam sesuai tuntutan Nabi Muhammad SAW.

Sesuai dengan fungsi Majelis Ta'lim tersebut, maka harapan Majelis Ta'lim Asyifah dapat mempunyai penerus agar lebih banyak lagi yang mendapatkan pengetahuan tentang ajaran agama islam, namun kenyataannya di Kecamatan Pattallassang Kab Takalar belum ada Majelis Ta lim yang lain yang bisa meneruskan apa yang telah dilakukan oleh Majelis Ta`lim Asyifah tersebut.

Sejalan dengan perkembangan dan tuntutan masyarakat maka pola pengembangan da'wah Majelis Ta'lim tidak cukup hanya berorientasi kepada tema-tema da'wah yang sifatnya menghibur dan menentramkan, tetapi juga bersifat memperluas dan meningkatkan yaitu meningkatkan wawasan dan kualitas keilmuan khususnya ilmu pengetahuan agama yang menjadi dasar kehidupan manusia sebagai umat agama.

\section{METODE PENELITIAN}

Jenis penelitian ini adalah penelitian kualitatif yang bersifat deskriptif, penentuan informan melalui purposive sampling. Fokus penelitian adalah Eksistensi Majelis Ta'lim di
Kecamatan Pattallassang Kabupaten Takalar. Instrumen penelitian adalah peneliti sendiri dan dibantu tape recorder dan kamera. Sumber data dari data primer dan data sekunder. Dalam penelitian ini peneliti menggunakan cara-cara untuk melakukan penelitian seperti wawancara, dokumentasi dan observasi. Teknik analisi data melalui beberapa tahapan yaitu Reduksi Data (Data Reduction, Penyajian Data (Data Display, Penarikan Kesimpulan dan Verifikasi (Conclusion Drawing/Verification. Dalam hal pengabsahan data, peneliti menggunakan metode tringulasi yang diartikan sebagai pengecekan data dari sumber yang kribel atau berbagai cara yang relefan dan berbagai waktu yang tepat sesuai dengan prinsip efektifitas dan efesiensi data penelitian.

\section{PEMBAHASAN}

\section{Sejarah berdirinya Majelis Ta lim Asyifah}

Majelis Ta’lim Asyifah di Kecamatan Pattallassang Kabupaten Takalar pertama kali atau didirikan sekitar tahun 2013. Berdirinya Majelis Ta'lim tersebut atas pemikiran para tokoh masyarakat Kecamatan Pattallassang sendiri yang melihat kondisi keagamaan dan sosial masyarakat khususnya para ibu rumah tangga pada saat itu memang memerlukan penguatan, penyegaran dan pembimbingan.

Mejelis Ta'lim yang diikuti ibu rumah tangga di Kecamatan Pattallassang merupakan tempat atau ajang menimba ilmu pengetahuan tentang agama bagi para ibu rumah tangga yang ada di Kecamatan Pattallassang. Pada awal berdirinya jumlah jamaah Majelis Ta'lim di Kecamatan Pattallassang Cuma diikuti oleh beberapa orang saja, akan tetapi seiring berjalannya waktu jumlah jamaah semakin bertambah. Sampai saat ini jumlah jamaah Majelis Ta`lim Asyifah di Kecamatan Pattallassang ada sekitar 30 orang.

Majelis Ta'lim Asyifah diadakan atau dilaksanakan setiap kamis sore, yang dimulai sekitar pukul 15.30-17.30. adapun susunan acara pengajian yang ada di Majelis Ta'lim Asyifah diantaranya sebagai berikut: (a) Shalat Berjamaah (Shalat ashar), (b) Sholawatan, (c) Membaca Al Quran, (d) Istirahat, (e) Isian atau tausiyah dan do`a 
Tujuan Majelis Ta’lim Asyifah adalah: (a) Untuk meningkatkan keimanan dan ketaqwaan kepada Allah SWT, (b) Mendidik dan membina anggota untuk berilmu, beramal dan berakhlakul karimah, (c) Untuk memupuk rasa persaudaraan diantara para anggota, (d) Sebagai sarana untuk meningkatkan shalat berjamaah dan pengajian di lingkungan kecamatan pattallassang dan sekitarnya, (e) Menambah pengetahuan agama dan ketenangan batin

Berdasarkan tujuan kegiatan-kegiatan Majelis Ta’lim Asyifah sesuai dengan teori yang dikemukakann Tuti Alawiyah bahwasanya dari pengalaman selama ini, Majelis Ta lim merupakan tempat berkumpul dan tempat bermasyarakat. Sambil berkumpul, waktu yang tersedia disisi dengan bersama membaca Al Qur’an. Para jamaah mendapat pelajaran agama dari seseorang guru tetap. Dalam kesempatan-kesempatan tertentu, mereka memperingati hari-hari besar islam.

Bentuk-bentuk kegiatan yang ada di Majelis Ta`lim Asyifah adalah: (a) Pengajian rutin. Pengajian rutin Majelis Ta`lim Asyiah adalah kegiatan yang dilaksanakan kamis sore dengan tujuan memperoleh ilmu dan kemampuan khususnya ilmu agama Islam dan para jamaah bisa mengaplikasikannya dalam kehidupan sehari-hari. (b) Kegiatan mujahabah. Kegiatan ini bertujuan untuk mengingat Allah dan bertaqwa kepadanya (c) Tadarusan. Kegiatan ini bertujuan untuk menambah ilmu dan keyakinan kepada Allah SWT, (d) Peringatan maulid Nabi Muhammad SAW dan Isra Miraj. Kegiatan ini bertujuan untuk menignkatkan kesadaran dan kesejahteraan rumah tangga dan lingkungan.

2. Faktor-faktor penyebab tidak adanya penerus Majelis Ta`lim Asyifah di Kecamatan Pattallassang Kabupaten Takalar

Majelis Ta`lim merupakan salah satu lembaga pendidikan keagamaan khas islam. Lembaga ini hampir terdapat disetiap komunitas islam yang keberadaannya telah banyak berperan dalam pengembangan dakwah islam. Melalui Majelis Ta’lim masyarakat yang terlibat di dalamnya dapat merasakan betapa keberadaan lembaga ini menjadi sarana pembinaan moral spritual serta menambah pengetahuan keislaman guna meningkatkan kualitas sumber daya muslim yang beriman dan bertakwa kepada Allah SWT.

Proses pengajaran keislaman di Majelis Ta`lim Asyifah sangat fleksibel bersifat terbuka serta tidak terikat oleh kondisi tempat dan waktu. Namun yang terjadi di lapangan tepatnya di Kecamatan Pattalassang Kabupaten Takalar Majelis Ta`lim tidak memiliki penerus yang akan meneruskan kegiatan-kegiatan yang telah dilakukan oleh Majelis Ta`lim terdahulu. Bahkan hingga kini keberadaan Majelis Ta`lim masih menjadi pilihan para pegiat dakwah sebagai sarana yang efektif dalam melanjutkan tradisi penyampaian pesan agama ke tengah-tengah umat tanpa terikat oleh suatu kondisi tempat dan waktu.

Kemudian Majelis Ta`lim juga merupakan salah satu tempat dan sarana dalam pendidikan pemberdayaan perempuan sebagai salah satu lingkup program pendidikan luar sekolah. Lingkup pendidikan luar sekolah mencakup pendidikan anak usia dini, pemberdayaan perempuan, pendidikan usia lanjut dan pendidikan komunitas.

Majelis Ta’lim Sebagai salah satu lembaga pendidikan non formal, Majelis Ta`lim bertanggungjawab untuk mendidik dan membantu jamaahnya untuk dapat beradaptasi dengan lingkungan masyarakatnya dan mampu memecahkan berbagai persoalan hidup yang dihadapinya. Tetapi tidak semua masyarakat di Kecamatan Pattallassang bisa mengikuti kegiatan yang dilakukan Majelis Ta`lim Asyifah ini.

Faktor penyebab tidak adanya penerus Majelis Ta`lim Asyifah adalah salah satunya karena kurang adanya sosialisasi tentang adanya kegiatan Majelis Ta'lim yang dilakukan oleh ibu-ibu pengajian di kecamatan pattallassang. Sosialisasi harus dilakukan agar lebih banyak lagi masyarakat yang bergabung dalam kegiatan Majelis Ta`lim Asyifah ini. Alasan dari perempuan remaja tidak ikut dalam kegiatan Majelis Ta`lim ini dikarenakan dia harus mengurus anak-anaknya yang masih kecil dan dia juga sebagai pembantu rumah tangga yang setiap hari di rumah orang dan itu dilakukannya seorang diri. Jadi dia tidak bisa membagi waktunya antara mengurus anak dan menjadi pembantu 
rumah tangga. Dia juga mengatakan bahwa kegiatan yang dilakukan oleh Majelis Ta'lim Asyifah itu sangat baik dan bermanfaat bagi masyarakat. Adapun kegiatan yang biasa dilakukan oleh para anggota Majelis Ta’lim Asyifah. Banyak kegiatan yang dilakukan oleh ibu-ibu pengajian Majelis Ta'lim Asyifah. Mulai shalat berjamaah ashar, mendengarkan ceramah dari ustadz, membaca surat-surat pendek, membaca shalawat, melakukan kegiatan tambahan yaitu arisan ibu-ibu anggota Majelis Ta'lim Asyifah dan terakhir makan makanan yang sudah disediakan oleh ibu-ibu.

Meski keberadaan Majelis Ta’lim mempunyai keunggulan-keunggulan sebagai sarana dan dakwah dan pembinaan sumber daya umat diakui masih memerlukan sejumlah pemikiran serta pembinaan serius dan komprehensif yang tidak hanya berorientasi pada sisi organisasi atau lembaga namun juga mengarah pada totalitas Majelis Ta 'lim. Pembinaan terhadap Majelis Ta'lim dimaksudkan untuk memaksimalkan peran dan fungsi demi sempurnanya pola-pola pelaksanaan dakwah yang dilakukan lembaga yang bernama Majelis Ta`lim.

Pergeseran tata nilai dalam kehidupan manusia ini sebagai salah satu akibat dari kemajuan ilmu pengetahuan dan teknologi, yang secara konkrit perubahan dan pergeseran itu membawa pada perilaku hidup umat yang mengejar kehidupan dunia sampai tidak menghiraukan halal dan haram sehingga melupakan hubungannya dengan Allah dan hubungannya dengan manusia. Untuk mengatasi hal serupa diatas perlu adanya pembinaan pengetahuan moral tentang ajaran agama Islam.

Pendidikan agama dan kegiatan kegiatan yang bernuansa keagamaan secara umum adalah hal yang sangat penting dalam memenuhi kebutuhan jiwa manusia dan membentuk kepribadian yang baik dan mulia, terutama pendidikan dan kegiatan-kegiatan keagamaan yang bernuansa Islam. Sisi lain, tantangan hari esok sangat berat, yang mengharuskan kondisi kebangsaan kita harus fit, sekaligus juga mempunyai kemampuan lebih atau tambahan untuk mampu bersaing dalam era tersebut.
Arus globalisasi yang menyebabkan pudarnya nilai moralitas, terjadinya sikap mementingkan diri sendiri (individualisme) sehingga kegiatan gotong royong dan kebersamaan dalam masyarakat mulai ditinggalkan; Terjadinya sikap materialisme, yaitu sikap mementingkan dan mengukur segala sesuatu berdasarkan materi karena hubungan sosial dijalin berdasarkan kesamaan kekayaan, kedudukan sosial atau jabatan. Adanya sikap sekularisme yang lebih mementingkan kehidupan duniawi dan mengabaikan nilai-nilai agama, dominannya nilainilai budaya yang melanggar nilai-nilai kesopanan dan budaya bangsa melalui media massa, masuknya budaya asing yang tidak sesuai dengan nilai-nilai budaya bangsa.

Majelis Ta'lim sebagai pintu gerbang pendidikan slam mau tidak mau harus menghadapi permasalahan yang muncul akibat dari dunia yang semakin mengglobal, bergerak dan berubah semakin cepat dan kompetitif. Majelis Ta'lim dituntut untuk terus dapat meningkatkan kualitas dirinya agar dapat berperan lebih besar dalam menjembatani kesenjangan yang terjadi antara kondisi nyata umat Islam dengan perkembangan dunia yang semakin maju serta menjadi agen perubahan(Agent of Change), membawa umat Islam menuju kondisi yang lebih maju sesuai dengan tujuan da'wah yaitu untuk mencapai masyarakat Khairul Ummah.

Munculya Majelis Ta'lim dewasa ini merupakan fenomena menarik. Majelis Ta'lim lahir bersamaan dengan kompleksitas persoalan yang dihadapi dimasyarakat, seperti pencurian, narkoba, seks bebas dan lain sebagainya. Oleh karena itu, bermula dari kesadaran masyarakat untuk membendung persoalan tersebut melalui pemahaman dan peningkatan nilai-nilai agama mutlak dilakukan.

Majelis Ta'lim tidak sekedar sebagai aktivitas keagamaan yang lebih mengutamakan aspek ritualistik, lebih jauh Majelis Ta'lim membenahi diri sebagai proses pendidikan, yang mengajarkan dan menanamkan nilai-nilai keagamaan pada anggotanya. Pendidikan Pemberdayaan perempuan adalah pendidikan yang mengangkat harkat dan martabat perempuan, mewujudkan kesetaraan dan 
keadilan gender dalam kehidupan berkeluarga, bermasyarakat, berbangsa dan bernegara. Menigkatkan kualitas kesehatan, keterampilan, kewirausahaan, kepemimpinan dan pembinaaan. Jenis pendidikan ini dilakukan dalam bentuk aturan pendidikan keluarga, kelompok belajar, penyuluhan, pelatihan Majelis Ta'lim dsb. Pembangunan pemberdayaan perempuan dilakukan untuk menunjang dan mempercepat tercapainya kualitas hidup dan mitra kesejajaran laki-laki dan kperempuan, dilaksanakan melalui kegiatan sosialisasi pendidikan dan pelatihan bagi kaum perempuan yang bergerak dalam seluruh bidang atau sektor.

Pada sisi lain, orang mulai menyesalkan hilangnya fungsi dan peran agama yang seharusnya bisa membimbing manusia dalam menghayati nilainilai agama untuk menumbuhkan nilai-nilai luhur pada kehidupan individual maupun sosial sehingga masyarakat modern tidak terjerat pada kebanggaan materi belaka. Pentingnya penanaman dan internalisasi nilai agama bagi masyarakat diera modern menjadi perhatian semua pihak dan kalangan. Orang tua dan anggota keluarga, juga banyak yang memiliki tanggung jawab yang sama dan pendidikan berperan amat mendasar dalam penanaman nilai-nilai agama tersebut.

Pergeseran paradigma dikalangan masyarakat yang hanya mementingkan hal-hal duniawi semata, hal ini membuat masyarakat menjauh dari apa-apa yang telah disyariatkan oleh agama. Padahal manusia diciptakan oleh Allah SWT selain untuk menjadi kholifah di bumi. Manusia mempunyai kewajiban menyembah kepada Allah SWT, jadi dalam mengarungi hidup itu memang harus seimbang, antara urusan dunia dan urusan akhirat dalam Abd. Majid (2000:45).

Majelis Ta'lim sebagai lembaga pendidikan non formal yang bergerak dibidang dakwah banyak sekali manfaatnya yang bisa diambil oleh masyarakat. Konsep yang ditawarkan Majelis Ta`lim dimana di dalamnya diajarkan banyak ilmu pengetahuan tentang agama islam. Selain menjadi ajang silaturahmi dikalangan masyarakat dan dapat menambah rekatnya hubungan persaudaraan. Majelis Ta`lim tidak hanya berfungsi sebagai tempat belajar agama islam, namun juga mampu memberi warna bagi jamaahnya dalam pembinaan solidaritas sosial yang kuat antar umat islam melalui silaturahhim.

Adapun upaya memaksimalkan eksistensi Majelis Ta’lim dalam Tuti Alawiyah (1997:95) adalah

a. Memperkuat fungsi Majelis Ta`lim sebagai tempat pengajaran agama islam secara luas, yang meliputi pengajian tentang pokok-pokok ajaran islam dan kaitannya dengan persoalan sehari-hari yang dihadapi oleh umat islam itu sendiri. Pengetahuan pokok ajaran islam seperti akidah, syariah akhlak, tafsir, hadits dan tarikh sudah semestinya diintegrasikan dengan sisi kehidupan nyata yang selalu muncul dalam keseharia umat. Hal ini diniscaya kan sesuai dengan sumber pokok ajaran islam, yaitu Alquran dan As sunnah yang menyajikan banyak hal yang bisa dipelajari oleh setiap muslim dalam mengikuti suri teladan yang dicontohkan oleh Nabi Muhammad SAW sebagai pembawa syariat islam. Kaitan islam dengan ilmu-ilmu terapakan yang berhubungan langsung dengan nafas kehidupan manusia dirumuskan dalam beberapa pokok pembahasan menyangkut hubungan islam dengan lingkungan, kesehatan, kesenian, politik dan psikoligi. Selain mengajarkan tentang ibadah transmental dalam arti hubungan vertikal antara manusia dengan Allah SWT, tapi juga mencakup bagaimana seharusnya seorang muslim menjalin hubungan horisontal dengan sesama manusia dan lingkungannya.

b. Meningkatkan fungsi Majelis Ta'lim dari tempat penyelenggaraan pengajian menjadi wahana melakukan kaderisasi umat Islam. Kaderisasi adalah suatu sistem menyiapkan generasi yang akan datang. Sistem ini dikemas dan diaktualisasikan dengan sungguh di Majelis Ta’lim. Setiap Majelis Ta'lim sesuai dengan tujuan, misi dan visinya harus melakukan pengakaderan dikalangan jamaahnya. Dengan demikian keberlangsungan Majelis Ta'lim akan terus berlanjut. 
c. Mengembangkan fungsi konseling. Sebagai salah satu lembaga pendidikan non formal, Majelis Ta’lim bertanggungjawab untuk mendidik dan membantu jamaahnya untuk dapat beradaptasi dengan lingkungan masyarakatnya dan mampu memecahkan berbagai persoalan hidup yang dihadapinya. Melalui kegiatan Majelis Ta'lim yang dikemas sedemikan rupa diharapkan dapat membantu jamaah yang mengalami persoalanpersoalan kehidupan, baik pribadi maupun sosial. Dalam situasi seperti inilah peran dan fungsi konseling akan terasa diperlukan oleh berbagai pihak yang terlibat di Majelis Ta`lim terutama para jamaahnya.

d. Menjadikan Majelis Ta'lim sebagai pusat pengembangan keterampilan atau skill jamaah. Setiap muslim idealnya bisa berperan ganda dalam kehidupannya, yaitu sebagai abid atau penyembah Allah dan sekaligus sebagai Khalifah (orang yang memakmurkan bumi). Sebagai penyembah Allah SWT, seorang muslim mesti ikhlas menjadikan hidupnya sebagai media pengabdian diri kepada-Nya. Dan sebagai pemakmur di muka bumi, setiap muslim harus berperan dalam mencegah dan memperbaiki kerusakan-kerusakan yang terjadi disekelilingnya. Dalam konteks ini Majelis Ta`lim bisa menjadikan pusat pengembangan keterampilan atau skill bagi jamaahnya. Keterampilan yang dimaksud sesuai keterampilan yang dimaksud sesuai dengan aneka ragam bakat yang dimiliki oleh setiap individu dalam Majelis Ta'lim tersebut. Keterampilan yang dapat dikembangkan meliputi keterampilan dasar yakni membaca, menulis, berbicara dll. Keterampilan hidup sehari-hari yang berfungsi untuk melakukan aktifitas untuk memenuhi kebutuhan sehariharinya.

e. Meningkatkan peran pemberdayaan manusia melalui pengembangan potensi ekonomi dan sosial. Sebagai tempat berkumpulnya jamaah, Majelis Ta lim diharapkan bisa menjadi media sosial dalam mengkomunikasikan upaya-upaya pembangunaan umat, baik secara lahir maupun batin. Melalui Majelis Ta`lim yang merupakan sarana efekti dalam interaksi sosial dapat disampaikan informasi yang dapat menggugah jamaahnya untuk berfikir dan melalukan langkah-langkah produktif dalam rangka pemberdayaan ekonomi dapat bersifat mandiri maupun menjalin kerjasama dengan donator, baik pemerintah maupun swasta.

f. Menjadikan Majelis Ta'lim sebagai wadah silaturrahmi dan reaksi ruhani. Majelis Ta'lim tidak hanya berfungsi sebagai tempat belajar agama Islam, namun juga mampu memberi warna bagi jamaahnya dalam pembinaan solidaritas sosial yang kuat antar umat islam melalui silaturahhim. Selain itu juga, Majelis Ta`lim bisa memberikan ruang yang cukup lapang dalam menjalankan fungsi reaksi rohani melalui nasehat-nasehat dan pesan-pesan moral yang diajarkannya. Dalam situasi dan kondisi itulah, melalui Majelis Ta'lim akan tertanam harmoni sosial yang dapat dipetik oleh semua jamaah yang kemudian mengkondisikan suatu jalinan kebersamaan sebagai hamba-hamba Allah yang sama-sama mempunyai hajat mengisi ruang hati dengan siraman-siraman dakwah islamiyah.

g. Mengembangkan fungsi sebagai pusat komunikasi dan informasi. Melalui pengembangan fungsi ini diharapkan jamaah akan selalu mendapatkan informasi yang yang update mengenai perkembangan sosial budaya yang terjadi disekitarnya maupun perkembangan dunia yang terjadi dengan sangat cepat. Sebagai pusat informasi, Majelis Ta`lim melalui pengurusannya mampu untuk mengumpulkan, menyiapkan, memproses dan menyaring berita, data, opini dan komentar secara jelas serta memberikan petunjuk dan arahan bagaimana seharunsya jamaah menyikapi semua hal-hal yang terjadi.

h. Mengembangkan peran sebagai tempat berkembangnya budaya Islam. Sebagai institusi pendidikan nonformal Majelis Ta'lim dapat menciptakan budayanya sendiri, misalnya budaya dalam berpakaian dan perhiasan yang tentunya mencerminkan bagaimana seharusnya jamaah atau masyarakat yang terlibat di 
dalamnya untuk selalu membiasakan tata cara berpakaian yang sesuai dengan ajaran islam. Begitu pula dalam hal budaya makanan, minuman dan kebiasaan-kebiasaan lainnya.

Majelis Ta'lim yang ada di Kecamatan Pattallassang ini merupakan tempat untuk menimba ilmu pengetahuan agama bagi masyarakatnya khususnya bagi ibu-ibu rumah tangga. Selain sebagai ajang menimba ilmu, Majelis Ta’lim Asyifah juga sebagai ajang silaturahmi antar tetangga. Hal tersebut dapat ditinjau dari ketika ada jama'ah atau tetangga yang sedang mengalami musibah, maka dengan secara cepat direspon oleh tetangga atau jama ah yang lainnya karena sudah ada ikatan dalam Majelis Ta'lim. Maraknya kaum ibu yang terlibat dalam aktivitas dakwah Islam di berbagai Majelis Ta'lim tentu patut disyukuri. Karena bagaimana pun juga dakwah Islam bukanlah monopoli atau tanggungjawab kaum Adam saja. Kaum hawa pun memiliki peran yang sama untuk mensukseskan dakwah Islam. Majelis Ta'lim sebagai lembaga non formal di masyarakat merupakan sarana yang sangat potensial untuk menyampaikan dakwah Islam dan membina masyarakat. Jumlah Majelis Ta'lim amat banyak, hampir tersebar diseluruh provinsi, kabupaten/kota, bahkan hingga ke tingkat RW dan RT. Majelis Ta'lim menjangkau seluruh lapisan masyarakat mulai dari masyarakat kelas atas, menengah hingga kelas bawah.

Proses pengajaran keislaman di Majelis Ta'lim sangat fleksibel, bersifat terbuka tempatnya bisa dilakukan di rumah, mesjid atau mushollah. Begitu pula dengan waktu penyelenggaraannya yang dilaksanakan pagi siang sore atau malam hari. Kegiatan Majelis Ta`lim Asyifah ini sangat fleksibel yang dilakukan setiap kamis sore sehingga tidak mengganggu kegiatan lain ibu rumah tangga. Masih banyak kegiatan lain yang bisa dilakukan oleh para ibu rumah tangga setiap hari. Seperti mengurus anak-anaknya, pergi ke sawah, ke kantor dll. Kegiatan Majelis Ta'lim ini sama sekali tidak mengganggu kegiatan ibu-ibu tersebut.

Peran Strategis Majelis Ta'lim

Mengingat karakteristik dan jumlah anggota Majelis Ta lim yang bisa mencapai jutaan orang jangan heran bila saat ini Majelis Ta lim sering menjadi salah satu target incaran strategis dalam aneka kepentingan sosial-politik banyak pihak terkait dengan Election Based On Popular Vote.

Pertama, sebagai media transformasi nilainilai Islam dalam keluarga. Melalui Majelis Ta'lim kaum ibu bisa menambah khazanah ilmu yang berguna untuk membangun keluarga Islam yang kokoh. Antara keluarga dan ibu seperti dua sisi mata uang logam yang tak bisa dipisahkan sebagai instrumen untuk membangun peradaban Islam. Sejatinya fungsi dan peran perempuan muslimah dalam mengembankan risalah dakwah ialah dengan menjaga, merawat, dan mengajarkan nilai-nilai agama kepada anak-anak mereka. Peran ini begitu dibutuhkan ditengah era globalisasi yang menawarkan hidup hedonis, individualis, dan materialis. Jika semua ibu sudah mampu mentransformasi nilai-nilai Islam dalam kehidupan keluarganya, maka tidak mustahil jika agama islam akan berkembang dan maju serta mampu meraih masa keemasannya kembali sebagaimana pada masa silam. Perubahan kualitas suatu bangsa lebih efektif jika diawali dengan perubahan kualitas kaum perempuan. Mengingat peran signifikan seorang perempuan sebagai istri, ibu dan anggota masyarakat. Sebagai pendamping suami sekaligus sebagai motivator perubahan dalam keluarga. Maka tidak berlebihan bila ada ungkapan yang mengatakan bahwa ibu adalah madrasah pertama bagi anak-anaknya. Bahkan ada juga yang mengatakan, "Perempuan itu tiang negara, apabila perempuan itu baik maka baiklah negara itu dan apabila perempuan itu rusak, maka rusaklah negara itu."

Kedua, membina dan mengembangkan dakwah Islam. Latar belakang lahirnya Majelis Ta`lim pada awalnya adalah untuk mengembangkan dakwah Islam. Disini lah tempat mengkaji berbagai ilmu keislaman. Dengan kajiankajian keislaman yang intens diharapkan Majelis Ta`lim kaum ibu dapat melahirkan muslimahmuslimah tangguh yang memiliki semangat untuk berdakwah. Jadi, Majelis Ta“lim tak hanya sekadar menjadi media transformasi ilmu keislaman saja, 
tetapi juga berperan melakukan kaderisasi juru dakwah berkualitas.

Ketiga, pemberdayaan ekonomi umat. Dengan jumlah anggota yang bisa mencapai ratusan bahkan ribuan orang, majelis taklim memiliki potensi yang luar biasa untuk mensejahterakan dan memberdayakan perekonomian umat. Program ini bertujuan agar umat Islam tak menjadi korban para rentenir. Banyak masyarakat perdesaan yang mengandalkan jasa rentenir untuk memenuhi hajat hidupnya. Karena memang tidak ada pilihan lagi.

Keempat, forum silaturrahim dan dialog. Keberadaan Majelis Ta'lim sangat bermanfaat untuk membangun silaturrahim kaum ibu. Manfaat yang didapatkan ketika bergabung dalam Majelis Ta`lim adalah silaturahmi dan dialog. Dari silaturrahim ini diharapkan terjadi dialog-dialog guna membahas persoalan perempuan, agama, maupun negara. Sehingga Majelis Ta lim berperan pula sebagai Problem Solving yang kerap menelurkan gagasan bermanfaat bagi masyarakat banyak. Selain itu Majelis Ta 'lim juga dapat menjadi lembaga advokasi kaum perempuan yang mengawal kepentingan atau hak-hak perempuan.

\section{Proses terciptanya penerus Majelis Ta'lim Asyifah}

Islam adalah ajaran dakwah yang berisi tentang petunjuk mengajak manusia secara individual maupun kelompok menjadi mannusia yang baik, beradab dan berkualitas, selalu berbuat baik sehingga mampu membangun sebuah tatanan kehidupan yang manusiawi dalam arti kehidupan yang adil, maju bebas dari berbagai ancaman, penindasan dan berbagai kekhawatiran agar masyarakat suatu bangsa tidak terpengaruh dengan lingkungan sekitar yang dikhawatirkan dapat membawa dampak negatif baik bagi individu itu sendiri maupun bagi bangsa maka diperlukan dakwah.

Dakwah bagian yang tidak terpisahkan dengan pembangunan bangsa dan negara karena keduanya memilki hakikat yang sama, yakni membangun manusia secara lahir dan batin, spritual dan material, duniawi dan akhirat. Melalui dakwah umat islam dimotivasi untuk partisipasinya dalam pembangunan nasional. Organisasi kemasyrakatan islam yang bergerak dibidang dakwah dan kemasyarakatan mempunyai peranan penting dalam pembangunan bangsa indonesia. Sebab lembaga dakwah telah mampu membuktikan eksistensinya sebagai pemberi motivasi dan nafas keagamaan pembangunan bangsa. Seiring perkembangan zaman, manusia dari hari ke hari semakin tidak menentu, keadaannya baik itu segi moralitas keagamaan maupun kehidupan sosial, ekonomi atau politik. Jadi sudah sepantasnya masyarakat muslim ini untuk melakukan dakwah baik secara lisan, tulisan, melalui media dan alat yang dapat memperbaiki keimanan individu, kelompok ataupun masyarakat melalui Majelis Ta`lim. Adanya Majelis Ta’lim ini merupakan salah satu lembaga yang bergerak dibidang dakwah dan kemasyarakatan berupa pengajaran ilmu-ilmu keislaman dengan memberikan bimbingan dan arahan kepada masyarakat. Majelis Ta’lim masih menjadi pilihan para penganut dakwah sebagai sarana paling efektif dalam melanjutkan tradisi penyampaian pesan-pesan keagamaan.

Kesibukan seringkali menggoda manusia untuk melupakan Allah SWT. Melupakan saudaranya sesama muslim dan bahkan melupakan dirinya sendiri. Adapun usaha yang dilakukan agar terciptanya penerus Majelis Ta`lim, harus ada langkah yang harus dilakukan jika ingin memiliki penerus Majelis Ta'lim Asyifah ini. Seperti harus dilakukannya sosialisasi tentang kegiatan yang dilakukan dalam Majelis Ta'lim dan juga harus Perlu adanya peran pemerintah dalam mensosialisasik an tentang Majelis Ta’lim. Mungkin masih banyak masyarakat lain yang tidak mengetahui adanya kegiatan Majelis Ta`lim ini sehingga mereka tidak bergabung dalam kegiatan ini. Cara ini bukan cuman ketua Majelis Ta'lim Asyifah yag melakukannya tetapi juga mayarakat dan tokoh agama dan tokoh masyarakat bisa bekerja sama dalam melakukan sosialisasi ini.

Berdasarkan hasil observasi dan wawancara di Kecamatan Pattallassang Kabupaten Takalar maka dapat dikatakan bahwa proses pengajaran keislaman di Majelis Ta’lim Ayifah sangat fleksibel bersifat terbuka serta tidak terikat oleh kondisi 
tempat dan waktu. Namun yang terjadi di lapangan tepatnya di Kecamatan Pattalassang Kabupaten Takalar Majelis Ta'lim tidak memiliki penerus yang akan meneruskan kegiatan-kegiatan yang telah dilakukan oleh Majelis Ta'lim terdahulu. Bahkan hingga kini keberadaan Majelis Ta'lim masih menjadi pilihan para pegiat dakwah sebagai sarana yang efektif dalam melanjutkan tradisi penyampaian pesan agama ke tengah-tengah umat tanpa terikat oleh suatu kondisi tempat dan waktu.

Eksistensi Majelis Ta`lim beserta perangkatnya sebagai lembaga pendidikan dan dakwah serta lembaga kemasyarakatan telah tumbuh dan berkembang bersama warga masyarakatnya sejak berabad-abad. Oleh karena itu secara kultural lembaga ini bisa diterima, tetapi juga ikut serta membentuk dan memberikan corak serta nilai kehidupan kepada masyarakat yang senantiasa tumbuh dab berkembang. Figur kyai, jama'ah serta seluruh perangkat fisik yang menandai sebuah Majelis Ta'lim senantiasa dikelilingi oleh sebuah kultur yang bersifat keagamaan. Dari uraian di atas dapat dipahami bahwa Majelis Ta'lim adalah suatu lembaga non formal yang mengajarkan dan menyampaikan ajaran-ajaran atau pengetahuan tentang agama Islam. Tujuan dari Majelis Ta'lim yang pertama untuk meningkatkan iman dan bertakwa kepada Allah SWT. Yang kedua untuk membina akhlak yang mulia dan menjaga huungan antar sesama muslim dan lingkungan sekitar. Kemudian Majelis Ta'lim sebagai suatu lembaga pendidikan dan dakwah adalah suatu lembaga yang tidak terikat waktu dan tempat karena waktu dan tempat itu sendiri tidak tetap atau dapat beruah sesuai dengan kesepakan masyarakatnya. Dan Majelis Ta 'lim ini boleh diikuti oleh seluruh umat islam. Di dalam suatu Majelis Ta'lim terdiri atas seorang Ustads dan para jama'ah.

Tantangan pendidikan dan dakwah Islam semakin hari semakin kompleks, selain dituntut untuk memberi jawaban atas masalahmasalah domestik ajaran Islam, juga ditantang untuk memberikan solusi atas beragam persoalan yang mengemuka akibat pola kehidupan yang saling terhubung satu sama lain. Saat ini telah terjadi dekadensi moral dan nilai budaya di masyarakat kita. Sebagian masyarakat lebih memilih berkomunikasi dengan kekerasan dari pada memajukan nalar dan akal sehat.

Majelis Ta'lim sebagai pintu gerbang pendidikan Islam mau tidak mau harus menghadapi permasalahan yang muncul akibat dari dunia yang semakin mengglobal, bergerak dan berubah semakin cepat dan kompetitif. Majelis Ta'lim dituntut untuk terus dapat meningkatkan kualitas dirinya agar dapat berperan lebih besar dalam menjembatani kesenjangan yang terjadi antara kondisi nyata umat Islam dengan perkembangan dunia yang semakin maju serta menjadi agen perubahan(agent of change), membawa umat Islam menuju kondisi yang lebih maju sesuai dengan tujuan da'wah yaitu untuk mencapai masyarakat khairu ummah.

Sesuai pembahasan yang di atas, teori yang bersangkutan dengan pembahsan adalah teori perubahan sosial. Teori Perubahan Sosial merupakan segala perubahan yang terjadi dalam suatu lingkungan sosial yang meliputi berbagai unsur dan menyebabkan terjadinya perubahan pada sistem sosial dalam lingkungan tersebut. Dan berbagai lembaga masyarakat yang mempengaruhi sistem sosial, termasuk didalamnya nilai-nilai sosial, sikap, pola perilaku antara kelompok-kelompok dalam masyarakat Darwis dalam Selo Soemardjan (2009:35).

Majelis Ta'lim sebagai lembaga non formal yang mempunyai kedudukan dan fungsi sebagai alat dan sekaligus sebagai media pembinaan dalam beragama (da'wah Islamiyah), hal ini dapat dirumuskan fungsi Majelis Ta'lim sebagai berikut : (a) Membina dan mengembangkan ajaran Islam dalam rangka membentuk masyarakat yang bertaqwa kepada Allah SWT. (b) Sebagai taman rekreasi rohaniyah karena penyelenggaraanya bersifat santai. (c) Sebagai ajang berlangsungnya silaturrohnmi masa yang dapat menghidup suburkan da'wah dan ukhuwah Islamiyah. (d) Sebagai sarana dialog berkesinambungan antara ulama dengan umat. (d) Sebagai media penyampaian gagasan yang bermanfaat bagi pembangunan umat dan bangsa pada umumnya. 
Dilihat dari segi tujuan, Majelis Ta'lim termasuk sarana dakwah Islamiyah yang secara self standing dan self disciplined mengatur dan melaksanakan berbagali kegiatan berdasarkan musyawarah untuk mufakat demi untuk kelancaran pelaksanaan Majelis Ta'lim Islami sesuai dengan tuntutan pesertanya.

\section{KESIMPULAN}

Merujuk pada pokok permasalahan serta memperhatikan tujuan penelitian, maka penulis dapat menyimpulkan hasil penelitian ini sebagai berikut: (a) Pendidikan Majelis Ta'lim Asyifah berbeda dengan pendidikan madrasah dan pesantren. Pendidikan Majelis Ta'lim termasuk pendidikan non formal. Sebagai pendidikan non formal Majelis Ta'lim merupakan pendidikan yang diselenggarakan untuk mengembangkan potensi peserta didik dengan penekanan pada penguasaan pengetahuan dan keterampillan fungsional serta pengembangan sikap dan kepribadian professional yang diselenggarakan dalam masyarakat. (b) Majelis Ta'lim Asyifah berperan mempertahankan nilai-nilai keagamaan. Pendidikan yang diselengarakan oleh Majelis Ta'lim Asyifah sesuai dengan konsep pendidikan sepanjang hayat. Pendidikan tidak kenal usia dan berlaku dari lahir sampai mati. Pendidikan Majelis Ta'lim Asyifah merupakan pendidikan berbasis masyarakat dan memberikan pendidikan kepada masyarakat pada semua tingkatan umur. Oleh karena itu, pendidikan Majelis Ta'lim Asyifah dapat digunakan sebagai sarana untuk menginternalisasikan nilai-nilai ajaran Islam, sehingga nilai-nilai Islam tidak luntur dengan nilai-nilai lain yang tidak sesuai. Peran Majelis Ta'lim Asyifah dalam mempertahankan nilai-nilai keagamaan tentunya ditemukan pendukung dan penghambatnya. Faktor pendukungnya adalah partisipasi masyarakat dan pemahaman agama secara benar, sedangkan faktor penghambatnya adalah pengaruh budaya luar yang tidak sesuai dengan norma Islam dan gaya hidup masyarakat yang serba materialistik.

\section{DAFTAR PUSTAKA}

[1] Alawiyah, Tuti. (1997). Strategi Dakwah di Lingkugan Majelis Tak'lim. Bandung: Penerbit Mizan.
[2] Aminuddin. (2002). Pendidikan Agama Islam. Jakarta: Penerbit Ghalia Indonesia

[3] Hasbullah. (1999). Sejarah Pendidikan Islam di Indonesia. Jakarta: PT Raja Grafindo Persada

[4] Kardisi, Ravik. (2007). Pendidikan Akhlak Mulia Serta Religius. Jakarta: Penerbit PT. Rajawali Pers

[5] Khozin. (1997). Jejak-jejak Pendidikan Islam di Indonesia. Jakarta: Penerbit Bumi Aksara

[6] Majid, Abd. (2000). Tantangan dan Harapan Umat Islam di Era Globalisasi. Bandung: Penerbit CV. Pustaka Setia

[7] Marimba. (1992). IImu Pendidikan Dalam Perspektif Islam. Jakarta: Penerbit Rajawali

[8] Muhsin. (2009). Manajemen Majelis Ta lim. Jakarta: Penerbit Pustaka Indonesia

[9] Nata Abuddin. (2010). IImu Pendidikan Islam. Jakarta: Penerbit Kencana

[10] Notoadmojo. (2003). Pendidikan dan Perilaku kesehatan. Jakarta : Penerbit PT. Rineka Cipta

[11] Sunarto dan Hartono, (2008). Perkembangan Peserta Didik. Jakarta: Penerbit PT. Rajawali Pers

[12] Soekanto, Soerjono. (1992). Sosiologi Suatu Pengantar. Jakarta: Penerbit Rajawali

[13] Titarahardja dan La Sulo. (2008). Pengantar Pendidikan. Jakarta : Penerbit Renika Cipta

[14] Tirtarahardja Umar. (2000). Pengantar Pendidikan. Jakarta: Penerbit Rineka Cipta

[15] Zuhairi. (1997). Sejarah Pedidikan Islam. Jakarta; Penerbit Bumi Aksara

[16] Undang-undang republik Indonesia nomor 20 tahun 2003 tentang Sistem Pendidikan Nasional, bab II,pasal 361.

[17] UU Sikdisnas tahun (2003) tentang Pengertian dan Tujuan Pendidikan Nasional

[18] Asdiar. (2014), Pandangan Keluarga Pemulung terhadap Pendidikan Formal di Kecamatan Sinjai Utara Kabupaten Sinjai. Skripsi tidak diterbitkan.Makassar; Unismuh Makasar

[19] Nurhidayah. (2015), Pergeseran Nilai Sosial Budaya (Studi Implementasi Ajaran Syariat Islam Pada Masyarakat Madimeng Kabupaten Pinrang. Skripsi tidak diterbitkan.Makassar : Unismuh Makassar

[20] Nurzaila. (2014). Sistem Pendidikan Komunitas Kajang. Skripsi tidak diterbitakan. Makassar. Unismuh Makassar.

[21] Bappenas. (1982). Pendidikan dan Generasi Muda. (Online) Jilid 3 No 12 (http://www. Bappenas.go.id)diakses 11 Januari 2016)

[22] Mariah. (2006). Pengertian Eksistensi , (Online) Jilid 3,No.23, (blogspot.co.id.html) diakses, 5 Mei 2016

[23] Selo Soemardjan. (2010). Teori Perubahan Sosial, Jurnal Teori Sosiologi, (Online) Jilid 11,No.29, (blogspot.co.id.html) diakses, 10 Februari 2016) 